\title{
Congratulation and Positive Politeness Strategies in Iranian Context
}

\author{
Hamid Allami \\ English Dept, Yazd University, Yazd, Iran \\ Email: hamid_allami@yahoo.com \\ Maryam Nekouzadeh \\ English Dept, Yazd University, Yazd, Iran
}

\begin{abstract}
The present study investigated the nature of the speech act of congratulation in terms of the Taxonomy proposed by Elwood (2004), representing the basic verbal strategies used by Iranian Persian speakers in offering congratulations. Based on the modified version of Brown and Levinson's model of politeness (1987), it further explored the positive politeness strategies in the congratulation speech act. Fifty informants filled in a discourse completion test, consisting of 9 situations related to happy news. The analysis of the data revealed that the mostly used types of congratulation strategies were "Illocutionary Force Indicating Devise (IFID)", "Offer of good wishes" and "Expression of happiness". Regarding the positive politeness strategies the result was indicative of the fact that Iranian people mostly made use of the strategies "Giving gift to listener", "Exaggeration" and "In-group identity marker" when responding to other's happy news.
\end{abstract}

Index Terms - sociopragmatics, speech acts of congratulation, commiseration, Persian

\section{INTRODUCTION}

When something good happens to a person, it is common for others to express positively their ideas and feelings about it. It is considered a sign of jealousy if the other person who hears the good news doesn't show or express his/her pleasure on what has happened to the addressee. In a situation of happy news speakers mostly try to show their happiness by saying "congratulations", however, the patterns and expressions they use to express congratulations may vary in different situation (Elwood, 2004).

Congratulation is classified as an expressive speech act by which the speaker expresses his feelings and emotions towards the hearer (Searl, 1976). It is an act which is desirable to the person who has achieved something, showing the speaker's happiness. When someone congratulates, he/she shows that he/she shares in the other's joy.

According to Searl (1969. p. 67) there are the following rules for congratulation:

1) There is some event that is related to the hearer.

2) The event is in the hearer's interest and the speaker believes the event.

3) The speaker is pleased at the event.

4) It counts as an expression of pleasure at the event.

Triantafyllides (1941, cited in Marki-Tsilipako, 2001) considers congratulation as an exclamatory expression which functions as a wish. Marki-Tsilipakon (2001) has stated that congratulation is the expression of speaker's joy and praise on a pleasurable event. Leech (1983, p. 106) classifies congratulation as "convivial" in terms of politeness, by which he means the type of illocutionary function which while expressing "the illocutionary goals coincide with the social goal." According to him these expressions are "intrinsically polite". Furthermore, congratulation is associated with the approbation and modesty maxims proposed by Leech (1983, p. 132). According to approbation maxims, the speaker should minimize dispraise of the addressee and maximize the praise of the addressee while the modesty maxim requires that the speaker minimize the praise of himself and maximize the dispraise of himself. Thus by congratulating the speaker maximizes the praise of the addressee.

On the other hand, the speech act of congratulation can be associated with the notion of face and politeness. Orecchioni $(2004,2005$, cited in Barthes, 2006) argues that congratulation as an expressive speech act is directly linked to positive politeness and is a face saving act since it aims at enhancing the addressee's positive face.

The present study is an attempt at a detailed analysis of the patterns and linguistic forms that Iranian people use to offer congratulation in different situations. It further investigates the types of positive politeness which are mostly used by people in those situations. The research questions which are touched upon in this investigation are:

1) What are the basic strategies and sub-strategies used by Iranians to express congratulation in naturally occurring speech?

2) What types of positive politeness strategies are more prevalent in the congratulations of these participants? 


\section{LITERATURE REVIEW}

The speech act of congratulation has been investigated in a limited range of studies. An early study on the sociopragmatic plane of congratulation was conducted by Garibova and Blair (1999) on holidays in Azerbaijan and occasions in which people offer their congratulations. According to these authors, in Azerbaijan, people have some holidays such as woman's day, Ramazan (Ramadan), Nourouz and Bayram( celebration of spring-March 20-21) in which they visit their relatives and offer congratulation to them by using some expressions such as "Bayramin Mübarək" "congratulation on holiday" and "Sənə (Sizə) uzun mör arezu edirəm." "I wish you long life". They also wish health, success and luck for each other.

Another relevant study was conducted by G. Emery (2000) on greeting, congratulation and commiserating in Omani Arabic. The study investigated only the congratulation expressions which old and young people use on the occasions of wedding, the birth of a baby and religious Eves. The findings revealed that for congratulation at the wedding, there were some differences between older women's and older men's congratulation and that of younger people. For instance, on the occasion of wedding, younger people used the term "Mabruuk" or "mbaarak" (May you be blessed), while older people favored the expression "allah ybaarak fil-amaar" (May God bless your lives). Moreover, older women wished the couple to have a boy as their first child by saying "ishallaah bikurkum wild" (God willing your first-born child be a boy). They also wished them a long life and fertility. But younger people did not follow the wishing custom. On the occasion of childbirth, women congratulated the mother by giving her money as a present and while visiting the baby, they use sympathetic expressions such as "ahwan anshaallaah" (get better soon God willing).

In her analysis of the differences between Greek "congratulation and "bravo", Marki-Tsilipako (2001) points out that in Greek culture, Greeks do not frequently use the expression "congratulation" as it may represent that the speaker belongs to the educated/urban class where the relationship between the addressee and the speaker is not very close. On the occasion of wedding, educated/urban people may use "congratulation" along with the expression of wishes: "[May] that you live" or "an auspicious wedding". Moreover, on the occasion of university graduation, they use the expression "have a successful career". Also, on the occasion of job promotion, they make use of the term "to your next promotion". The term "congratulation" in Greek which shows the distance between the speakers and hearers, is used in official occasions and with hand shake, rather than an embrace or a kiss which represents the intimacy.

On the other hand, it is not appropriate for the men to congratulate the mother unless they are closely related. They only congratulate the father using the expressions such as: "Yatrabba fi 'izzak wa ykuun wild saalitt" (may you raise him up to be a fine boy). Younger men use the expression "mabruuk"(congratulations). Another occasions for congratulation is New Year, returning from Hajj and the month of Ramadan. The more traditional formula for congratulation in New Year is "haneetu bi-barakaat il-éed/ní imtubil-éed" (congratulation on the blessing of the Eid). The expression "bi-shahr ramadaan-allaah yibaarak fiikum" (blessings on the advent of the holy month of Ramadan" is used as greeting in the holy month of Ramadan. On the occasion of returning from Hajj the formulae "Hajj mabruur wa dhanb maghfuur wa tijaara laa tabuur" (congratulation on the Hajj and the visit) is the most commonly used expression.

One of the most recent and significant study on the speech act of congratulation was conducted by Elwood (2004) on American and Japanese students. Her proposed taxonomy for the congratulation strategies was used as the framework for my present study. In her study, 45 American students writing in English, 45 Japanese students writing in English and 45 Japanese students writing in Japanese filled in a discourse completion test with seven situations in which three situations were related to responding to happy news such as grant, promotion and wedding. The results of the study showed that the patterns which were used for responding to good news vary in Japanese and English. Generally speaking, Americans mostly tended to ask questions and request for information, while Japanese students writing in English and Japanese were most likely to use self-related comments such as expression of envy, longing, chagrin or comment on one's future success. Also, there was variation among the situations in a way that "Illocutionary Force Indicating Device (IFID)" was the mostly used type of response in the situation of promotion, while in the situations of grant and wedding the "Expression of happiness" was the dominant type of response. Furthermore, the "Expression of validation" such as "you deserve it" was mostly used in the situation of grant by all the groups, whereas it was used only by Americans in the situation of wedding. Request for information such as "who's the lucky guy/ girl" was highly used by the three groups and mostly by the Americans in the situation of wedding. The other types of responses that were used by the groups in the three situations were: "Offer of good wishes", "A suggestion to celebrate", "Offer of good luck" and "Encouragement".

Another important study has been conducted by Akram (2008) on speech acts in Urdu and English. According to the results of this study, on special occasions such as Christmas, English speakers use the expression "Happy Christmas" and Urdu speakers say "ko/ tumheir nya saal mubarak ho". In New Year, English speakers say "Happy New Year", while Urdu speakers use the term 'Mubarak'. Also, for birthday English speakers say "happy birthday", whereas Urdu speakers us the expression "Raat Mubara". Besides, the expressions that are used in religious holidays in Urdu are as follow: "Mahe Ramezan Mubarak" (congratulation on Ramezan) and "Eide-Milad-u-Nabi Mubarak" (congratulations on birth of the Imam). Akrams' further points out that all these English expressions are used by native speakers, while the three last expressions in Urdu are mostly used by young girls and women and are not as common as other 
expressions. Furthermore, it is concluded that all the stated expressions in English and Urdu can be used both formally and informally except for the last expression that is "Eide-Milad-u-Nabi Mubarak" which is used in formal situations.

\section{METHOD}

\section{A. Participants}

The participants of this study were 50 males and females with the age range of 17 -75 with different socio-economic backgrounds.

\section{B. Data Collection}

The present research project was conducted in Isfahan, Iran. The data were collected by asking the participants to fill in a Discourse Completion Test consisting of 9 situations dealing with happy news (see Appendix). All these situations were designed based on the combination of two variables: social status with three levels: low (L), high (H), and equal (E) and social distance with three levels: intimate (I), acquaintance (A) and stranger (S). Samples of congratulation expressions were encoded and analyzed based on the taxonomy of congratulation strategy proposed by Elwood (2004) and further they were analyzed according to the classification of positive politeness strategies proposed by Brown and Levinson (1987, pp. 102-131). However there is a minor modification to capture salient strategies used in the present study.

Congratulation Strategies and Sub-strategies Coding

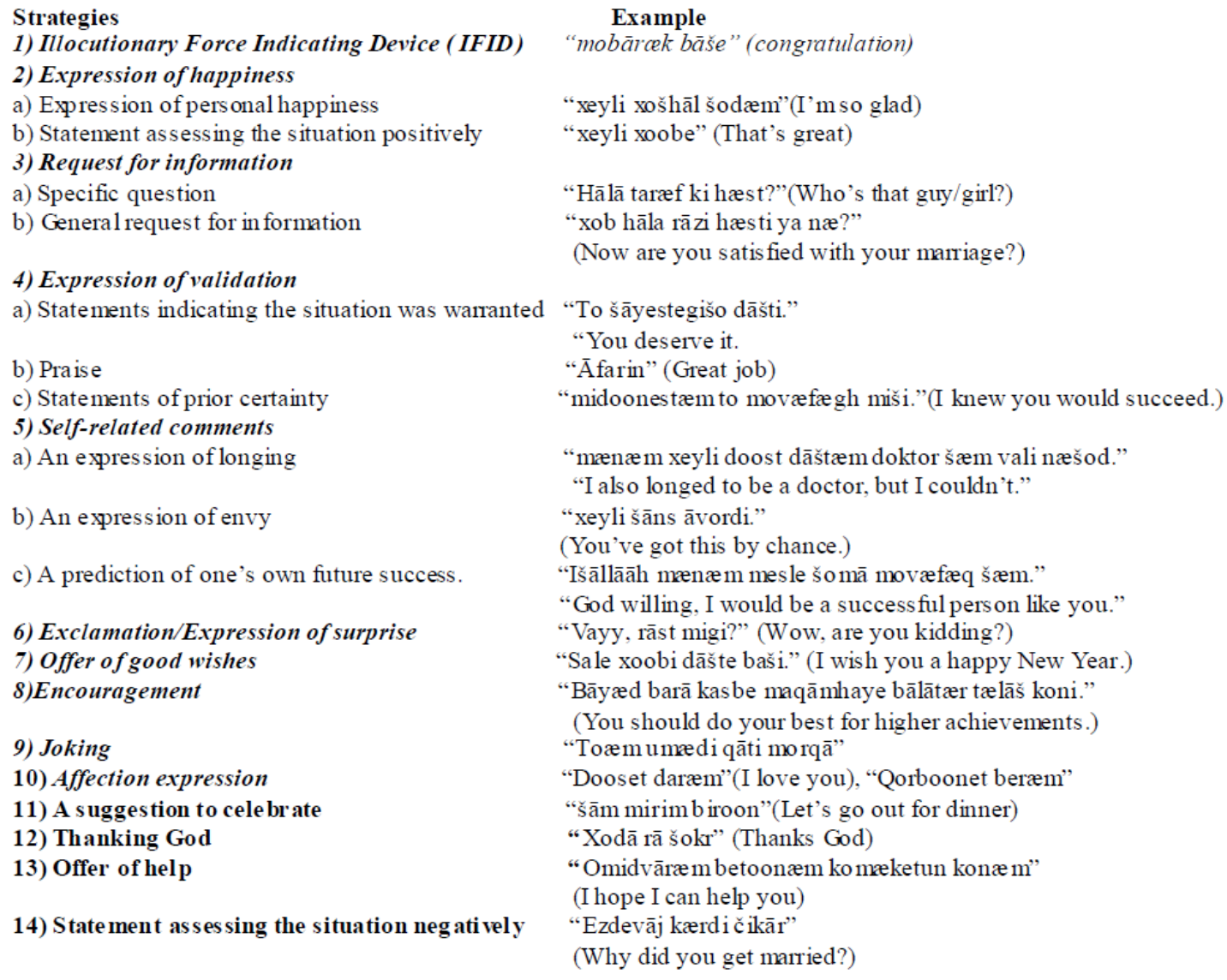

14) Statement as ses sing the situation neg atively

"You deserve it.

"Āfarin" (Great job)

"midoonestæm to movæfægh miši."(I knew you would succeed.)

"mænæm xeyli doost dāštæm doktor šæm vali næšod."

"I also longed to be a doctor, but I couldn't."

"xeyli šāns āvordi."

(You've got this by chance.)

"Išāllāāh mænæm mesle šo mā movæfæq šæm."

"God willing, I would be a success ful pers on like you."

"Vayy, rāst migi?" (Wow, are you kidding?)

"Sale xoobi dāšte baši." (I wish you a happy New Year.)

"Bāyæd barā kasbe maqāmhaye bālātær tælāš koni."

(You should do your best for higher achievements.)

"Toæm umædi qāti morqā"

"Dooset daræm"(I love you), "Qorboonet beræm"

"šām mirim b iroon"(Let's go out for dinner)

"Xodā rā šokr" (Thanks God)

"Omidvāræm betoonæm ko mæketun konæm"

(I hope I can help you)

"Ezdevāj kærdi čikāi”"

(Why did you get married?) 


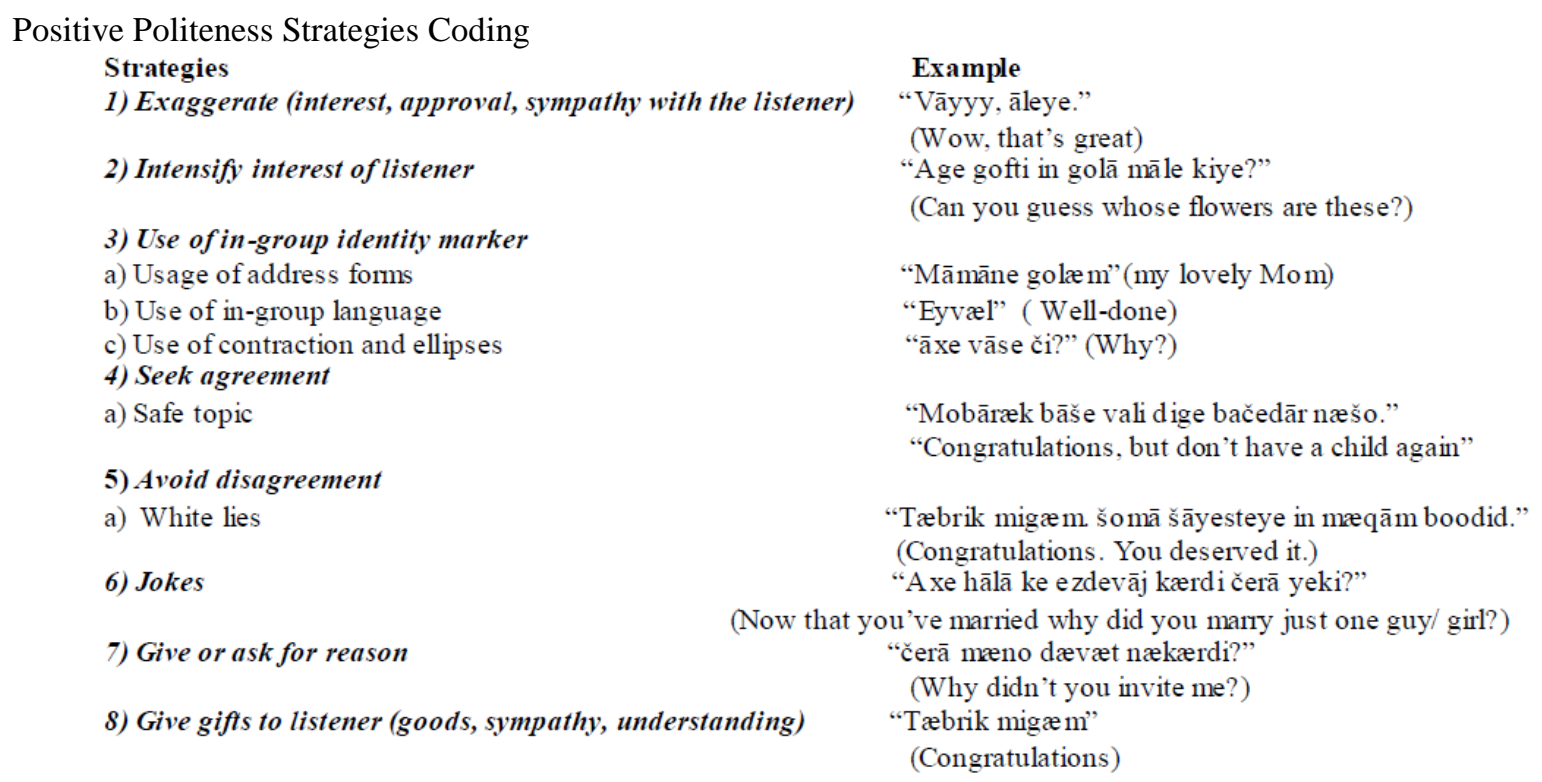

\section{RESULTS AND ANALYSIS}

\section{A. Situation 1: Wedding}

In this situation, $32 \%$ of the participants who completed the DCT used the "Illocutionary Force Indicating Device (IFID)": "Tábrik migam" or "mobārcek bāše" (Congratulations), while 16\% used "Exclamation/Expression of surprise": (Wow) and 16\% used statements which showed "Expression of personal happiness" such as:" Xeyli xošhālcem" (I'm so happy). Also, $10 \%$ of the participants assessed the situation positively with the most frequent type of formulation " $x e y l i$ $x u b$ " and "Bceh Baeh" (Great). Moreover, $10 \%$ of the people requested for general information by saying" če bixcebcer" (why didn't you inform me?) or "xob hālā rāzi hoesti?"(Are you satisfied now?). Only $2 \%$ of the participants asked specific question about the identity of spouse as "bā ki ezdevaj kærdi?"(Who did you marry?). The other types of responses that were used in this situation were: "Offer of good wishes" (4\%):" Inšāllāāh xošbcext bešil" (God willing, become prosperous) and use of "Jokes" (6\%): "Hālā ke ezdevāj kardi čerā yeki?" (Now that you've got married why did you marry one guy/girl?). Besides, in this situation in $18 \%$ of cases, "Offer of good wishes" was used after "IFID", in $6 \%$ of responses this strategy followed a "Statement assessing the situation positively", whereas in $6 \%$ of cases it was seen after the "Expression of personal happiness". What is more, 5\% of people used "Joking" after using "IFID".

Regarding the positive politeness strategies in this situation, the most frequently used strategies were "Giving gifts to the listener" (50\%) such as "mobārcek bāše" (congratulation) or "āfcerin" (well-done) and "Exaggeration" (18.8\%) such as "äliye" (great). In $9 \%$ of cases, use of "In-group language" such as "Eyval" (very good) and "omaedi qāti morqā" (you've got married) were seen. Furthermore, "Jokes" (6\%), "Give or ask for reason" (6\%): “čerā mæno xæbær nækærdi?"(Why didn’t you let me know?), "Safe topic" (3\%): "Mobārak bāše vali aege ezdevāj nemikardi behtaer bud" (Congratulations but it was better if you wouldn't get married) and "Use of address forms": "Azizam" (my darling) were seen among the responses.

\section{B. Situation 2: Grant}

In this situation, 64\% of people used statements with "IFID" and $18 \%$ of people used "Expression of personal happiness". Also, "Offer of good wishes" such as "Inšāllāāh movafaeq bāš i" (God willing, be successful) constituted $(10 \%)$ of responses. The other types of responses which were uyilized rarely included "Praise" (6\%) such as "šoma bāese eftexāre mā hastid" (We are proud of you) and "statements indicating the situation was warranted" (2\%) such as "šomā šāyesteye in mæqām budid" (you deserve it). What is more, 18\% of responses included "Offer of good wishes" following "IFID". Moreover, in 4\% of cases "Joking” followed "Expression of personal happiness".

Considering the positive politeness strategies; "Giving gifts to listener" and "Exaggeration" comprised 94\% and 6\% of the responses respectively.

\section{Situation 3: Getting Trophy}

In this situation, the most frequently used congratulation strategies were "Praise" (36\%) and "IFID" (14\%). In addition, $8 \%$ of the responses were statements of "Encouragement", while $10 \%$ of them were "Expression of personal happiness". Besides, in $8 \%$ of cases, the participants used "Expression of validation" which indicated "Prior certainty" such as "man midoonestam to barandeh miši" (I knew that you would be successful). The other types of strategies used in this situation were "Statements assessing the situation positively" (4\%), "Exclamation" (6\%), "Offer of good wishes" (6\%), "A suggestion to celebrate" (2\%), "Affection expression" (2\%) and "Thanking God" (4\%). Furthermore, 
in $8 \%$ of responses "Praise" followed "Offer of good wishes". Furtheremore, in one of the responses, "Joking" was used after the use of "Praise" and in one response "Statements indicating the situation was warranted" followed "Praise". Moreover, in this situation, one of the participants used "Praise" after "Expression of surprise".

Regarding the positive politeness strategies used in this situation, $63 \%$ of responses included "Giving gifts to listener" and $22 \%$ of them consisted of "Exaggeration". Moreover, $8 \%$ of people used "In-group language". Other utilized strategies were "Safe topic" (2\%), "Jokes" (2\%) and "Use of address forms" (2\%).

\section{Situation 4: Promotion}

The most frequently used congratulation strategy in this situation was "IFID" (60\%). Also, in $20 \%$ of responses, "Offer of good wishes" was used and in $4 \%$ of responses, the situation was warranted. In addition, $6 \%$ of participants used a "Self-related comment" which was a statement of envy: "in maqām haqe man bood" (it was I who deserved this). What is more, $2 \%$ of responses were statements of "Praise" and 2\% were "A suggestion to celebrate". Moreover, in this situation, $30 \%$ of people offered good wishes after congratulating and only in one case, "Offer of help" followed "Offer of good wishes". Furthermore, $4 \%$ of responses included "Prediction of one's own future success" after "IFID".

With regard to positive politeness strategies, "Giving gifts to listener" comprised $85 \%$ of responses, while $15 \%$ of the responses included "White lies" (Although the people congratulated the addressee, they stated that they had a feeling of jealousy).

\section{E. Situation 5: Birthday}

In this situation, $76 \%$ of people used "IFID". Moreover, $16 \%$ of responses included "Affection expression". In these cases, the expressions were followed by "Offer of good wishes" such as" Sæd sāl zende bāši” (have a long life). Also, in $8 \%$ of responses, "Offer of good wishes" was the only type of utilized strategy. In $20 \%$ of cases, "IFID" was followed by "Offer of good wishes". Besides, in two of the responses "IFID" was used after the "Affection expression".

Considering the positive politeness strategies, "Giving gift to listener "was the most highly utilized strategy (84\%). "Use of address forms" and "In-group language" comprised $8 \%$ and $4 \%$ of responses respectively. "White lies" (2\%) and "Intensifying interest of listeners" (2\%) were also seen among the responses.

\section{F. Situation 6: Graduation}

In this situation, $50 \%$ of responses felled into the category of "IFID". Also, $12 \%$ of the participants expressed their personal happiness and $24 \%$ of them offered good wishes as their responses. Furthermore, $10 \%$ of the responses were the expression of "Praise", while 4\% of them included the strategy of "Joking". One person used "Encouragement" strategy and one of them used the strategy of "A suggestion to celebrate". Besides, in 16\% of responses in this situation, "Offer of good wishes" followed "IFID".

Regarding the positive politeness strategies, as in other situations "Giving gift to listener" was the mostly used strategy $(87 \%)$. Other types of used politeness strategies were: "Intensifying interest of the listener" (2\%), "Use of ingroup language" (2\%), "Jokes" (4\%), and "Exaggeration" (4\%).

\section{G. Situation 7: New Year}

In this situation, $78 \%$ of responses contained "IFID", whereas $18 \%$ of them were statements which offered good wishes. Besides, $4 \%$ of the people used "Expression of personal happiness." In addition in $28 \%$ of cases, "Offer of good wishes" followed "IFID", while in 6\% "Joking" followed this strategy.

With regard to positive politeness strategies $87 \%$ of the participants used "Giving gifts to listener". Also "Jokes" were used in $2 \%$ of cases and "Usage of address forms" was seen in $10 \%$ of responses.

\section{H. Situation 8: Arrival of a Baby}

$62 \%$ of the responses in this situation included "IFID". In $12 \%$ of cases, "Exclamation or Expression of surprise" was used. $6 \%$ of people "Assessed the situation negatively" such as" Bače mixāsti čikār" (What's the use of the child?). $8 \%$ of responses were "Request for specific information" about the identity of the baby such as "doxtare yā pesar?" (is it a girl or a boy?). $6 \%$ of people used "Offer of good wishes" and $4 \%$ of responses were "Expression of personal happiness". Only in $2 \%$ of cases, the participants "Assessed the situation positively". Additionally, in $12 \%$ of responses the participants used "Offer of good wishes" after using "IFID" and in 6\% of the responses, they employed "Specific question". Also, in this situation after "Expression of surprise" one of the participants made use of "Specific question" and one of them used "IFID" strategy.

With respect to positive politeness strategies, again the mostly utilized strategy was "Giving gift to the listener" (82\%). Also, "Safe topic" was stated in $8 \%$ of responses. Other types of used strategies were "Exaggeration" (4\%), "Intensifying interest of the listener" (2\%), "Use of address forms" (2\%) and "Use of Contraction and ellipses" (2\%).

\section{Situation 9: Educational Achievement}

In this situation, $24 \%$ of responses included "Offer of good wishes" and $22 \%$ of the participants made use of "Praise". In $20 \%$ of the cases, "IFID" was seen and $20 \%$ of the participants assessed the situation positively by saying "xeyli xoobe" (very good) or "āleye" (great). 2\% of the respondents used "Expression of longing" such as "moen homiše delam mixāst ke doktor š cem cemā naš̌od" (I have always longed to be a doctor, but I couldn’t manage it). In $12 \%$ of 
cases, people used "Statements of personal happiness" and in 6\% of responses, "Expression of surprise" was seen. Furthermore, in one of the responses "An Expression of longing" was used after "Expression of happiness" and in one of them, "Joking" followed the strategy "Praise".

Concerning the positive politeness strategy, "Giving gifts to listener" was utilized in $82 \%$ of cases, while "Exaggeration", "Use of in-group language" and "White lies" were seen in 10\%, $4 \%$ and $4 \%$ of responses respectively.

\section{CONCLUSION}

This study sought to discover the congratulation strategies used most often by Iranian Persian speakers and the types of positive politeness strategies they use to realize congratulation speech act.

Generally speaking, five types of congratulation strategies, namely "Illocutionary Force Indicating Device (IFID)", "Expression of happiness", "Offer of good wishes", "Request for information" and "Expression of validation" were the major types of strategies utilized by the people. "IFID" and "Offer of good wishes" were used in all the situations. "Expression of happiness" was also seen in all the situations except the situation of "birthday'. "Thanking God", "A suggestion to celebrate" and "Offer of help" were the least utilized congratulation strategies. What is more, the greatest number of utilized strategies was used in situation 1 (wedding) and situation 3 (getting a trophy), while the smallest number of strategies were seen in situation 7 (New Year). In the situations of 'wedding' and 'getting a trophy' people used 9 and 11 congratulation strategies respectively, whereas in the situation of 'New Year', they used only 3 types of strategies.

Considering the positive politeness strategies within the congratulation speech act, the analysis of the data revealed that the most highly utilized positive politeness strategies was "Giving gift to listener" which was used with the highest frequency in all situations. "Exaggeration" and "In-group identity marker" were also applied by the people in most of the situations. "Joking", "White lies", "Safe topic" and "Giving or asking for reason" were the least types of utilized politeness strategies applied by the people to realize the act of congratulation. Moreover, the greatest and the smallest number of used positive politeness strategies were seen in situations of 'wedding' and 'Grant' in which people made use of 8 and 2 types of politeness strategies respectively.

APPENDIX 


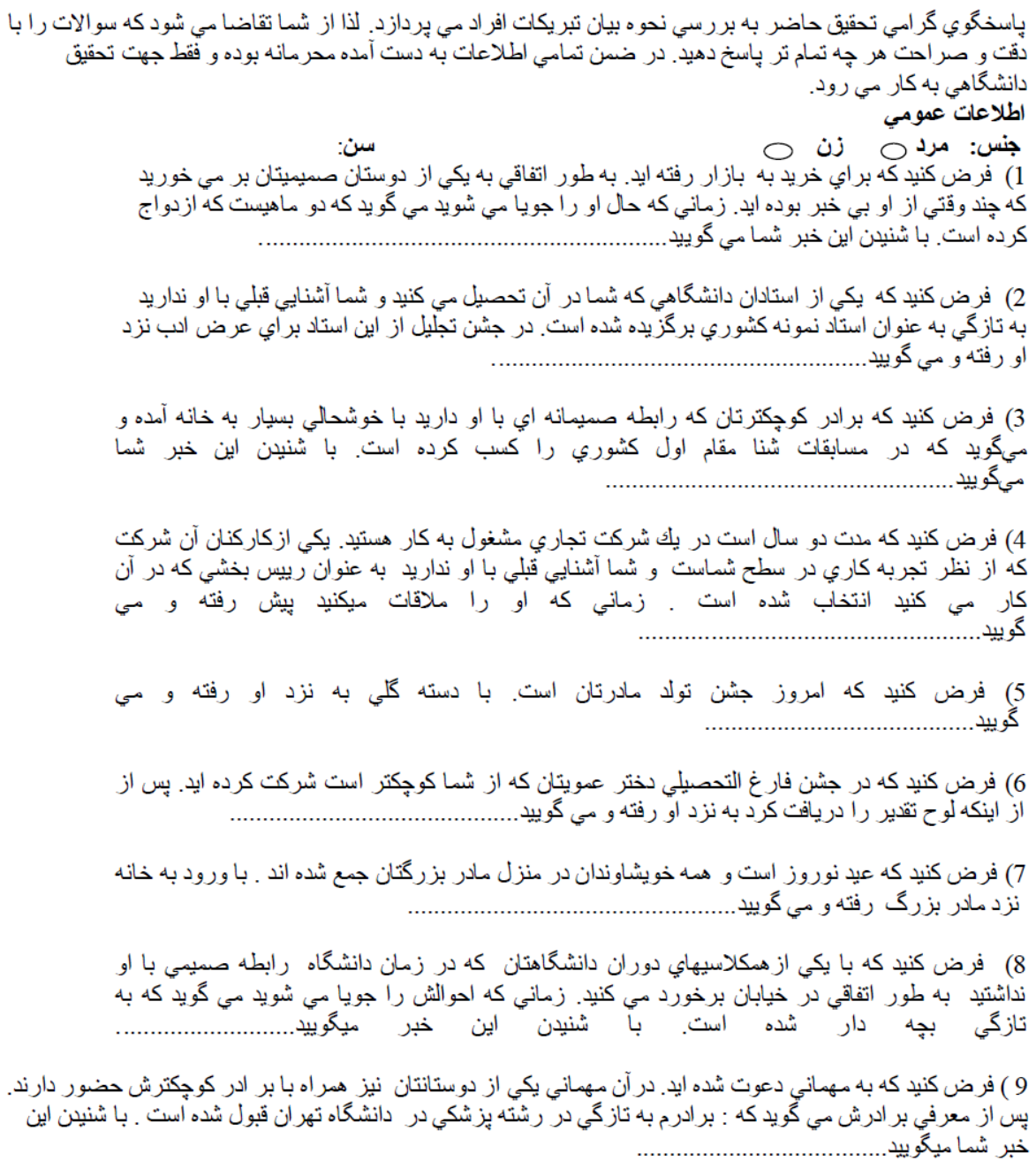

\section{REFERENCES}

[1] Akram, M. (2008). A contrastive study of speech acts in Urdu and English. Asian EFL journal. 10, 4. 148-172

[2] Barthes, R.(2006). Noroc;Merci!quo!indo!;sorry! Some polite speech acts across cultures. Southwest journal of linguistics. [Retrieved July 21, 2010, from http://www.highbeam.com/doc/1G1-168292864.html]

[3] Brown, P., \& Levinson, S. (1987). Politeness: Some language universals in language use. Cambridge: Cambridge University Press.

[4] Elwood, K. (2004). "Congratulations": A cross-cultural analysis of responses to another's happy news. [Retrieved July 25, 2010, from http://dspace.wul.waseda.ac.jp/dspace/handle/2065/6097]

[5] G.Emery, P. (2000). Greeting, congratulation and commiserating in Oman Arabic. Language, Culture and Curriculum.13, 2, 196-216.

[6] Guribova, J. \& Blair, B.(1999). Holidays in Azerbaijan, sociolinguistics speaking- part2. Azerbaijan International.7, 1. [Retrieved July 23, 2010 from http://azeri.org/Azeri/az_learn/az_socio/articles/az_socio_71/71_socio.html]

[7] Leech, G.(1983). Principles of pragmatics. London: Longman.

[8] Makri-Tsilipakou, M.(2001). Congratulation and bravo! In A. Bayraktaroglu \& M. Sifianou (Eds.), linguistic politeness across boundaries: The case of Greek and Turkish, pp.137-176.

[9] Searle, J. (1969). Speech acts: An Essay in the Philosophy of Language. Cambridge: Cambridge University Press.

[10] Searle, J. (1976). Classification of Illocutionary Acts. Language and society, 5, 1-23.

Hamid Allami is assistant professor of Applied Linguistics at Yazd University, Iran. His major areas of research include Sociopragmatics, Speech acts and Interlanguage Pragmatics. His has already published many articles in both national and international journals such as TELL, IJLS, Iranian EFL Journal, Linguistics Journal, and Journal of Pragmatics. He has also been a reviewer of articles to several journals such as Applied Linguistics, TELL and IJLS.

Maryam Nekouzadeh holds an MA in TEFL. She received her MA from Yazd University in 2010. She is currently teaching English to EFL learners at language institutes. 